\title{
Spatial variability of nitrous oxide in the Minho and Lima estuaries (Portugal)
}

\author{
Célia Gonçalves, Maria José Brogueira \\ Instituto Português do Mar e da Atmosfera, IPMA Rua Alfredo Magalhães Ramalho, 6, 1495-006, Lisboa, Portugal. \\ (CG) (Corresponding author) E-mail: celia.pgoncalves@ gmail.com. ORCID iD: http://orcid.org/0000-0001-5524-1256 \\ (MJB) E-mail: mjbrogueira@gmail.com. ORCID iD: http://orcid.org/0000-0003-3692-4099
}

\begin{abstract}
Summary: Nitrous oxide $\left(\mathrm{N}_{2} \mathrm{O}\right)$ is a potent long-lived greenhouse gas and estuaries represent potentially important sources of this biogas to the atmosphere. In this work, we analyse the first $\mathrm{N}_{2} \mathrm{O}$ data obtained in the Minho and Lima estuaries, and the processes and environmental factors that may regulate its production in these systems. In September 2006, $\mathrm{N}_{2} \mathrm{O}$ attained values of up to $20.0 \mathrm{nmol} \mathrm{L}^{-1}$ in the upper reaches of the Lima estuary and the river was, apparently, the main source of biogas to the system. In Minho $\mathrm{N}_{2} \mathrm{O}$ reached a maximum of $14.4 \mathrm{nmol} \mathrm{L}^{-1}$ and nitrification appeared to contribute to the enhancement of $\mathrm{N}_{2} \mathrm{O}$. In the upper estuary, the relatively high concentrations of nitrification substrate $\mathrm{NH}_{4}^{+}$, the positive correlations found between $\mathrm{N}_{2} \mathrm{O}$ level above atmospheric equilibrium $\left(\mathrm{N}_{2} \mathrm{O}\right)$ and apparent oxygen utilization and $\mathrm{NO}_{2}^{-}$, and the negative correlations between $\Delta \mathrm{N}_{2} \mathrm{O}$ and $\mathrm{NH}_{4}^{+}$and $\mathrm{pH}$ can be interpreted as in situ $\mathrm{N}_{2} \mathrm{O}$ production through pelagic nitrification. Principal component analysis gave evidence of considerable differences between upper estuaries, particularly in terms of higher $\mathrm{N}_{2} \mathrm{O}$ in Lima and $\mathrm{NH}_{4}{ }^{+}$in Minho. Surface waters of both estuaries were always $\mathrm{N}_{2} \mathrm{O}$-supersaturated (101-227\%) and estimated $\mathrm{N}_{2} \mathrm{O}$ emissions from Minho and Lima were $0.28 \mathrm{Mg} \mathrm{N}_{2} \mathrm{O}-\mathrm{N} \mathrm{yr}^{-1}$ and $0.96 \mathrm{Mg} \mathrm{N}_{2} \mathrm{O}-\mathrm{N} \mathrm{yr}^{-1}$, respectively, which represent a reduced fraction of $\mathrm{N}_{2} \mathrm{O}$ global emission from European estuaries.
\end{abstract}

Keywords: $\mathrm{N}_{2} \mathrm{O}$; greenhouse gas; fluxes; emission; Portuguese estuaries.

Variabilidad espacial del óxido nitroso en los estuarios del Miño y Lima (Portugal)

Resumen: El óxido nitroso es un poderoso gas de efecto invernadero y los estuarios representan potenciales fuentes de este biogás a la atmósfera. En este trabajo se analizan los primeros datos de $\mathrm{N}_{2} \mathrm{O}$ obtenidos en los estuarios de Miño y Lima, así como los procesos y factores ambientales que pueden regular su producción en estos sistemas. En septiembre de 2006, $\mathrm{N}_{2} \mathrm{O}$ alcanzó en el tramo superior del Lima valores de hasta $20,0 \mathrm{nmol} \mathrm{L}^{-1}$ y el río Lima fue, aparentemente, la principal fuente de biogás para el sistema. En el Miño $\mathrm{N}_{2} \mathrm{O}$ alcanzó una concentración máxima de $14,4 \mathrm{nmol} \mathrm{L}^{-1}$ y la nitrificación parece contribuir al aumento de $\mathrm{N}_{2} \mathrm{O}$. En el tramo superior del Miño las concentraciones relativamente altas del substrato de nitrificación $\mathrm{NH}_{4}{ }^{+}$y las correlaciones positivas encontradas entre el exceso de $\mathrm{N}_{2} \mathrm{O}\left(\Delta \mathrm{N}_{2} \mathrm{O}\right)$ y el consumo aparente de oxígeno (AOU) y $\mathrm{NO}_{2}^{-}$, y las correlaciones negativas entre $\Delta \mathrm{N}_{2} \mathrm{O}, \mathrm{NH}_{4}{ }^{+}$y $\mathrm{pH}$ pueden interpretarse como una producción in situ de $\mathrm{N}_{2} \mathrm{O}$ debido a la nitrificación pelágica. El Análisis de Componentes Principales evidenció diferencias considerables entre la cabecera de los estuarios particularmente en términos de mayor concentración de $\mathrm{N}_{2} \mathrm{O}$ en el Lima y $\mathrm{NH}_{4}{ }^{+}$en el Miño. Las aguas superficiales del Miño y del Lima presentaban sobresaturación de $\mathrm{N}_{2} \mathrm{O}$ (101-227\%) y las emisiones estimadas de $\mathrm{N}_{2} \mathrm{O}$ fueron de $0,28 \mathrm{Mg}$ de $\mathrm{N}_{2} \mathrm{O}-\mathrm{N}$ año-1 y $0,96 \mathrm{Mg}$ de $\mathrm{N}_{2} \mathrm{O}-\mathrm{N} \mathrm{año}^{-1}$, respectivamente, que representan una fracción reducida de las emisiones totales de $\mathrm{N}_{2} \mathrm{O}$ procedentes de los estuarios europeos.

Palabras clave: $\mathrm{N}_{2} \mathrm{O}$; gas de efecto invernadero; flujos; emisión; estuarios portugueses.

Citation/Como citar este artículo: Gonçalves C., Brogueira M.J. 2017. Spatial variability of nitrous oxide in the Minho and Lima estuaries (Portugal). Sci. Mar. 81(3): 317-326. doi: http://dx.doi.org/10.3989/scimar.04637.26A

Editor: X.A. Álvarez-Salgado.

Received: March 21, 2017. Accepted: June 14, 2017. Published: September 4, 2017.

Copyright: (0) 2017 CSIC. This is an open-access article distributed under the terms of the Creative Commons Attribution (CC-by) Spain 3.0 License.

\section{INTRODUCTION}

In the last few decades, the study of $\mathrm{N}_{2} \mathrm{O}$ has acquired greater importance due to its contribution to global climate change. $\mathrm{N}_{2} \mathrm{O}$ is an important long-lived greenhouse gas in terms of radiative forcing $(0.17 \pm 0.03$ $\mathrm{W} \mathrm{m}^{-2}$ ) (Myhre et al. 2013) and represents the major anthropogenic contributor to stratospheric ozone destruc- 
tion. It has a long atmospheric lifetime of $131 \pm 10$ years (Prather et al. 2012) and its global warming potential is 310 times greater than that of carbon dioxide, in a time horizon of 100 years. In 2011 atmospheric $\mathrm{N}_{2} \mathrm{O}$ levels $(324.2 \pm 0.1 \mathrm{ppb})$ exceeded the pre-industrial levels (270 \pm 7 ppb) by about 20\% (Myhre et al. 2013), largely due to increased agricultural activity and industry.

Estuaries have been considered significant $\mathrm{N}_{2} \mathrm{O}$ contributors to the atmosphere as a consequence of their high productivity and anthropogenic nitrogen loadings. $\mathrm{N}_{2} \mathrm{O}$ is mainly formed during the first step of nitrification, the aerobic oxidation of ammonium $\left(\mathrm{NH}_{4}{ }^{+}\right)$to nitrite $\left(\mathrm{NO}_{2}^{-}\right)$, mediated by ammoniaoxidizing bacteria (AOB) and ammonia-oxidizing archaea (AOA), and microbiological denitrification, the biological reduction of nitrate $\left(\mathrm{NO}_{3}{ }^{-}\right)$to $\mathrm{N}_{2} \mathrm{O}$, and, in turn, nitrogen gas $\left(\mathrm{N}_{2}\right)$. Nitrification and denitrification often occur simultaneously in aquatic ecosystems and their relative contribution to total $\mathrm{N}_{2} \mathrm{O}$ production is difficult to disentangle. As nitrification is an aerobic process in well-oxygenated estuarine systems, the water column mostly contributes $\mathrm{N}_{2} \mathrm{O}$ through nitrification production (de Wilde and de Bie 2000, Barnes and Upstill-Goddard 2011). Denitrification is usually limited to zones under hypoxic conditions (DO $<2 \mathrm{ml}$ $\mathrm{L}^{-1}$ ), although some denitrification may occur even in relatively oxygenated waters (de Bie et al. 2002).

Both nitrification and denitrification are sensitive to the ongoing environmental changes and any natural or anthropogenic-induced shifts in the $\mathrm{N}$ availability have the potential to alter nitrogen cycling in coastal envi- ronments and affect $\mathrm{N}_{2} \mathrm{O}$ formation and release to the atmosphere (Bange et al. 2010). The extent of the denitrification is also strongly controlled by temperature, nitrate concentrations and the availability of organic carbon (e.g. Dong and Nedwell 2006). In addition to the supply of oxygen and ammonia, which are the main controls on nitrification, other environmental variables may affect this biological process: temperature (Dai et al. 2008), salinity (Bollmann and Laanbroek 2002) and pH (Strauss et al. 2002).

Estimates of $\mathrm{N}_{2} \mathrm{O}$ release from estuaries to the global inventory reveal wide uncertainties due to the large variability in $\mathrm{N}_{2} \mathrm{O}$ data (Bange et al. 2010, Barnes and Upstill-Goddard 2011). However, considerable efforts have been made in the last few decades to better understand the nitrogen cycle, the dynamics of $\mathrm{N}_{2} \mathrm{O}$ production and the quantification of the respective emission from European estuaries. More recently Murray et al. (2015) reviewed $\mathrm{N}_{2} \mathrm{O}$ global fluxes from estuarine environments and reported a variation of 0.17-0.95 $\mathrm{Tg} \mathrm{N}_{2} \mathrm{O}-\mathrm{N} \mathrm{yr}^{-1}$.

Studies on the $\mathrm{N}_{2} \mathrm{O}$ dynamics and fluxes have been carried out in the Portuguese Tagus, Sado and Douro estuaries (e.g. Gonçalves et al. 2010, 2015, Teixeira et al. 2013). However, no data on $\mathrm{N}_{2} \mathrm{O}$ levels and fluxes are available for the Minho and Lima estuaries. In this work, we (1) report spatial variability of $\mathrm{N}_{2} \mathrm{O}$ concentration in these systems, (2) assess the contribution of different $\mathrm{N}_{2} \mathrm{O}$ sources, (3) evaluate the role of environmental properties on the increment of $\mathrm{N}_{2} \mathrm{O}$ fluxes, and (4) estimate $\mathrm{N}_{2} \mathrm{O}$ emission in a perspective of global $\mathrm{N}_{2} \mathrm{O}$ estuarine emissions.

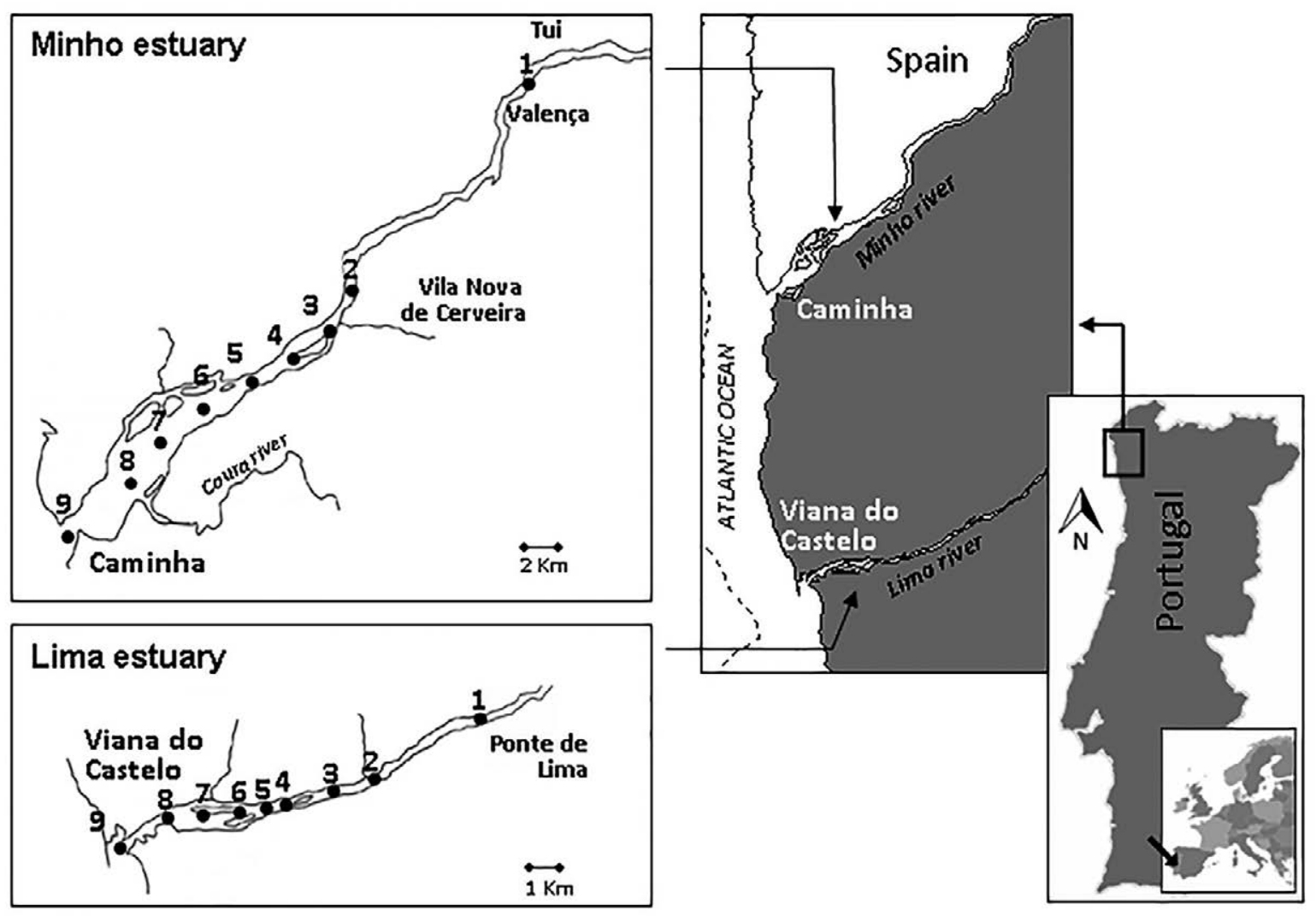

Fig. 1. - Map of the Minho and Lima estuaries. Dots and numbers represent sampling sites. 
Table. 1 - Main physical and hydrological characteristics of the Minho and Lima estuaries (Ferreira et al. 2005).

\begin{tabular}{lccccccc}
\hline Estuary & $\begin{array}{c}\text { Area } \\
\left(\mathrm{km}^{2}\right)\end{array}$ & $\begin{array}{c}\text { Mean depth } \\
(\mathrm{m})\end{array}$ & $\begin{array}{c}\text { Mean water } \\
\text { volume } \\
\left(\times 10^{6} \mathrm{~m}^{3}\right)\end{array}$ & $\begin{array}{c}\text { Mean residence } \\
\text { time }(\text { days })\end{array}$ & $\begin{array}{c}\text { Mean tidal } \\
\text { range }(\mathrm{m})\end{array}$ & $\begin{array}{c}\text { Mean annual fresh- Watershed population } \\
\text { water input } \\
\left(\mathrm{m}^{3} \mathrm{~s}^{-1}\right)\end{array}$ & $\begin{array}{c}\mathrm{N} \text { load } \\
(\mathrm{t} \mathrm{yr})\end{array}$ \\
\hline Minho & 23 & 2.6 & 70 & 1.5 & 3 & 300 & 20051 \\
$\left(\mathrm{hab} \mathrm{km}^{-2}\right)$
\end{tabular}

\section{MATERIALS AND METHODS}

\section{Area description}

The Minho and Lima estuaries, both situated in the northern part of Portugal (Fig. 1), differ essentially in terms of river discharge, anthropogenic pressures and morphology (Table 1).

\section{Minho estuary}

The Minho estuary is situated in the border region between Portugal (Minho region) and Spain (Galicia region). The estuary has an area of approximately 23 $\mathrm{km}^{2}$, a mean depth of $2.6 \mathrm{~m}$, and a maximum width of about $2 \mathrm{~km}$ at the confluence of the Coura River, at Caminha. The estuary is mesotidal, with a mean tidal range of $3 \mathrm{~m}$, and its dynamic tidal effects extends 35 $\mathrm{km}$ upstream (Bettencourt et al. 2003).

The annual mean discharge of the Minho River is $300 \mathrm{~m}^{3} \mathrm{~s}^{-1}$ (Table 1), ranging between approximately $100 \mathrm{~m}^{3} \mathrm{~s}^{-1}$ in August and $800 \mathrm{~m}^{3} \mathrm{~s}^{-1}$ in February, and the water residence time is 1.5 days (Sousa et al. 2013). The estuary has high ecological value, mainly due to the large diversity of habitats and biodiversity and great socio-economic importance from tourism, fishing and agriculture. However, increasing pressure has been detected over recent years, involving in particular the pollution of surface water from both specific and diffuse sources, morphological alterations, changes of land use in the drainage basin and other impacts from human activity, such as aquaculture, textile, rubber and plastic processing industries (Ferreira et al. 2005). The Minho and Coura rivers are the main nitrogen sources to the estuary, contributing $13000 \mathrm{t} \mathrm{N} \mathrm{yr}^{-1}$ and $7000 \mathrm{t}$ $\mathrm{N} \mathrm{yr}^{-1}$, respectively, and effluents from domestic origin contribute $51 \mathrm{t} \mathrm{N} \mathrm{yr}^{-1}$ (Ferreira et al. 2005) (Table 1).

\section{Lima estuary}

The Lima estuary, located south of Minho, has an area of approximately $5 \mathrm{~km}^{2}$ and a mean depth of $4 \mathrm{~m}$ (Table 1). It has a semidiurnal mesotidal regime and the tidal effect extends $20 \mathrm{~km}$ upstream (Ramos et al. 2006). The upper estuary is constituted by a narrow channel with some intertidal areas and undisturbed banks. The middle estuary is a shallow salt marsh zone, and the lower estuary consists of a wider and shallow basin that communicates with the sea via a deep, narrow channel (with a typical depth of about $10 \mathrm{~m}$ ). The estuary mouth is artificially obstructed by a 2-km-long jetty. The Lima River has an annual freshwater discharge of $54 \mathrm{~m}^{3} \mathrm{~s}^{-1}$, and the mean water residence time in the estuary is one day (Table 1).
The lower estuary is a highly urbanized zone and has been subjected to several anthropogenic impacts resulting from harbour activities (Viana do Castelo). However, nutrient loadings also originate from diffuse sources, largely agriculture $\left(0.51 \mathrm{t} \mathrm{N} \mathrm{yr}^{-1}\right)$, although the main $\mathrm{N}$ source to the estuary is the Lima River (1077 $\mathrm{t} \mathrm{N} \mathrm{yr}{ }^{-1}$ ) (Ferreira et al. 2005). This $\mathrm{N}$ load is, however, approximately 19 times lower than the load to the Minho estuary (Table 1).

\section{Sampling}

Water sampling was undertaken in September 2006 during ebb tide (at spring tide), at nine stations located along a main transect of both estuaries, from the upstream limit of tidal influence to the estuary mouth, covering a full range of salinity of 0-30 corresponding to a distance of $26.5 \mathrm{~km}$ in Minho and $15 \mathrm{~km}$ in Lima estuary (Fig. 1).

Surface water ( $0.2 \mathrm{~m}$ depth) was collected using 2-L Niskin bottles (General Oceanics) for analysis of salinity (S), temperature (T), $\mathrm{pH}$, dissolved inorganic nitrogen (nitrate $\mathrm{NO}_{3}{ }^{-}$, nitrite $\mathrm{NO}_{2}{ }^{-}$and ammonium $\mathrm{NH}_{4}{ }^{-}$), dissolved oxygen (DO) and nitrous oxide $\left(\mathrm{N}_{2} \mathrm{O}\right)$. The hydrological characteristics of the Minho and Lima estuaries and the meteorological conditions observed during the sampling period are presented in Table 2.

\section{Analytical procedure}

Water temperature $(\mathrm{T})$ was measured in situ with a Seabird SBE19/CTD probe with an accuracy of $0.01^{\circ} \mathrm{C}$.

Salinity (S) measurements were carried out using a temperature-controlled Guideline Salinometer (Portasal 8410A), and accuracy was 0.03 salinity. Equipment was calibrated with a certified IAPSO Standard Seawater reference.

Meteorological parameters (air temperature, pressure, and wind speed and direction) were determined using a portable meteorological station (Campbell Scientific CR510). Measurements represent the average of physical parameters taken using a sampling time of 5 seconds and a storage time of 1 minute. Wind speed 10-minute average was determined for each sampling

Table 2. - Hydrological characteristics of the Minho and Lima estuaries and meteorological conditions observed in September 2006. $\mathrm{Q}$, daily mean flow of the Minho and Lima rivers measured at Foz Mouro and Ponte da Barca, respectively (SNIRH 2013); $\mathrm{u}_{10}$, daily wind speed normalized to $10 \mathrm{~m}$ height.

\begin{tabular}{lcccc}
\hline Estuary & $\begin{array}{c}\text { Sampling } \\
\text { date }\end{array}$ & $\begin{array}{c}\text { Tidal amplitude } \\
(\mathrm{m})\end{array}$ & $\begin{array}{c}\mathrm{Q} \text { daily mean } \\
\left(\mathrm{m}^{3} \mathrm{~s}^{-1}\right)\end{array}$ & $\begin{array}{c}\mathrm{u}_{10} \\
\left(\mathrm{~m} \mathrm{~s}^{-1}\right)\end{array}$ \\
\hline Minho & 12 Sep & $0.6-3.3$ & 90.7 & $2.5-6.2$ \\
Lima & $13 \mathrm{Sep}$ & $0.9-3.1$ & 8.1 & $1.3-4.1$ \\
\hline
\end{tabular}


station and converted to wind speed values at $10 \mathrm{~m}$ height $\left(\mathrm{u}_{10}\right)$ using a logarithmic correction (Hartman and Hammond 1985).

The Minho and Lima River discharges were calculated as an average of the flow 10 days before sampling, at the hydrometric stations of Foz de Mouro and Ponte da Barca, respectively (SNIRH 2013).

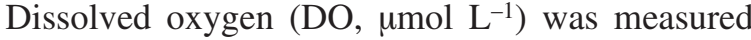
using whole-bottle Winkler's titration method (Aminot and Chaussepied 1983). A Methrom titrator was used to dispense small amounts of thiosulphate, and starch endpoint was detected visually. Precision of the method was in the range of $0.08 \%$ to $0.25 \%$. DO saturation, expressed in percentage $(\%)$, was determined as the ratio of the oxygen concentration determined and the equilibrium values of DO calculated with the Weiss (1970) equation. Apparent oxygen utilization (AOU, umol $\mathrm{L}^{-1}$ ) was calculated as the difference between the saturation oxygen concentration and the dissolved oxygen concentration measured in the sample.

Water samples for determination of dissolved inorganic nitrogen were filtered through acetate cellulose filters (pore size $0.45 \mu \mathrm{m}$ ) and stored at $-20^{\circ} \mathrm{C}$ until analysis. Analyses were carried out using a Traacs autoanalyser following colorimetric techniques outlined by the manufacturer. Estimated precision was $\pm 0.8 \%$ for nitrate and nitrite $\left(\mathrm{NO}_{3}{ }^{-}\right.$and $\left.\mathrm{NO}_{2}{ }^{-}\right)$and $\pm 2.0 \%$ for ammonium $\left(\mathrm{NH}_{4}^{+}\right)$, at mid-scale concentrations. Accuracy of nutrient measurements was maintained by using CSK Standards (WAKO, Japan).

$\mathrm{pH}$ measurement was carried out immediately after collecting water samples using a Metrohm 704 pH-meter and a combined electrode (Metrohm), standardized against NBS buffers $(6.865$ and $9.180 \mathrm{pH})$. Precision of $\mathrm{pH}$ measurements was \pm 0.01 .

Water samples for determination of $\mathrm{N}_{2} \mathrm{O}$ were collected in triplicate in $20-\mathrm{mL}$ glass headspace vials and poisoned with saturated aqueous mercury chloride $\left(\mathrm{HgCl}_{2}\right)$ to stop biological activity. The vials were stored upside down, in the dark, at $4^{\circ} \mathrm{C}$ in the refrigerator until analysis, performed within 10 days. Dissolved $\mathrm{N}_{2} \mathrm{O}$ was determined by a headspace equilibration technique coupled with gas chromatographic analysis (GC-3800, Varian). Briefly, $20 \mathrm{~mL}$ of sample was equilibrated with $5 \mathrm{~mL}$ of highly purified helium (purity $=99.9999 \%$ ) in a headspace CombiPAL autosampler. Gas chromatographic separation was carried out using a stainless steel column packed with 80/100 (mesh) Porapak. Oven and detector temperature was set at $50^{\circ} \mathrm{C}$ and $320^{\circ} \mathrm{C}$, respectively, and high purity nitrogen $(99.9999 \%)$ was used as the carrier gas (flow rate $\left.30 \mathrm{~mL} \mathrm{~min}^{-1}\right)$. To remove water vapour and carbon dioxide, absorbent columns packed respectively with $\mathrm{Mg}\left(\mathrm{ClO}_{4}\right)_{2}$ and Carbosorb were located in the carrier gas line between the sample loop and the separation column. $\mathrm{N}_{2} \mathrm{O}$ peak was detected with a ${ }^{63} \mathrm{Ni}$ electron capture detector (ECD). Calibration of ECD response was performed using standard gas mixtures with 400, 780 and $1980 \mathrm{ppb} \mathrm{N}_{2} \mathrm{O}$ in synthetic air (Air Liquide), and method precision was $2.6 \%$ (30 replicate measurements using samples containing $10 \mathrm{nmol} \mathrm{L}^{-1}$ of $\mathrm{N}_{2} \mathrm{O}$ ). In situ concentration of $\mathrm{N}_{2} \mathrm{O}\left(\mathrm{C}, \mathrm{nmol} \mathrm{L}^{-1}\right)$ was cal- culated from the concentrations measured in the headspace according to the solubility equation of Weiss and Price (1980):

$$
\mathrm{C}=\beta(\mathrm{TS}) \mathrm{x}^{\prime} \mathrm{P}
$$

where $\mathrm{x}^{\prime}$ is the measured $\mathrm{N}_{2} \mathrm{O}$ dry mole fraction, $\mathrm{P}$ is the atmospheric pressure, and $\beta$ is the solubility coefficient, which is a function of the water temperature (T) and salinity $(\mathrm{S}) . \mathrm{N}_{2} \mathrm{O}$ equilibrium concentrations were calculated assuming an atmospheric $\mathrm{N}_{2} \mathrm{O}$ mixing ratio of $320.1 \mathrm{ppb}$ (WMO 2006).

$\mathrm{N}_{2} \mathrm{O}$ saturation, expressed in percentage $(\%)$, was determined as the ratio between the measured dissolved $\mathrm{N}_{2} \mathrm{O}$ concentration and the equilibrium concentration. The $\mathrm{N}_{2} \mathrm{O}$ water-air flux $\left(\mathrm{F}_{\mathrm{N}_{2} \mathrm{O}}\right)$ was estimated according to the following equation:

$$
\mathrm{F}_{\mathrm{N}_{2} \mathrm{O}}=\mathrm{k}_{\mathrm{N}_{2} \mathrm{O}} \Delta \mathrm{N}_{2} \mathrm{O}
$$

where $\Delta \mathrm{N}_{2} \mathrm{O}$, the excess of $\mathrm{N}_{2} \mathrm{O}$, is the difference between the measured concentration and the equilibrium concentration with the atmosphere in the estuarine water at the local temperature and salinity; and $\mathrm{k}_{\mathrm{N}_{2} \mathrm{O}}(\mathrm{cm}$ $\mathrm{h}^{-1}$ ) is the $\mathrm{N}_{2} \mathrm{O}$ transfer velocity, which is expressed as a function of the wind speed and the Schmidt number (Sc). Since no direct measurements of $\mathrm{k}_{\mathrm{N}_{2} \mathrm{O}}$ were made in the Minho and Lima estuaries, both the k-wind relationships of Carini et al. (1996) (hereinafter referred to as C96) and Raymond and Cole (2001) (hereinafter referred to as RC01) were, respectively, used to compute $\mathrm{k}$ :

$$
\begin{gathered}
\mathrm{k}_{\mathrm{C} 96}=0.045+2.0277 \mathrm{u}_{10} \\
\mathrm{k}_{\mathrm{RC} 01}=1.91 e^{0.35 \mathrm{u}_{10}}
\end{gathered}
$$

The gas transfer velocities and air-sea fluxes were estimated using in situ wind speeds normalized to 10 $\mathrm{m}$ height $\left(\mathrm{u}_{10}\right)$. The $\mathrm{k}$ coefficients were corrected for in situ temperature using the following relationship:

$$
\mathrm{k}_{\mathrm{N}_{2} \mathrm{O}} / \mathrm{k}_{600}=\left(\mathrm{Sc}_{\mathrm{N}_{2} \mathrm{O}} / 600\right)^{-0.5}
$$

where $\mathrm{Sc}_{\mathrm{N}_{2} \mathrm{O}}$ is the Schmidt number for $\mathrm{N}_{2} \mathrm{O}$ calculated according to the equation of Wanninkhof (1992):

$$
\mathrm{Sc}=2301.1-151.1 \mathrm{~T}+4.7364 \mathrm{~T}^{2}+0.057431 \mathrm{~T}^{3}
$$

where $\mathrm{T}$ is the temperature $\left({ }^{\circ} \mathrm{C}\right)$.

\section{Statistical analysis}

An unpaired t-test was used to identify statistical differences in levels of $\mathrm{N}_{2} \mathrm{O}$ and other environmental variables between and along estuaries.

Pearson's correlation analyses were performed to evaluate the existence of relationships between $\Delta \mathrm{N}_{2} \mathrm{O}$ and the variables $\mathrm{NH}_{4}{ }^{+}, \mathrm{AOU}, \mathrm{NO}_{2}^{-}$and $\mathrm{pH}$ assumed to be connected with production pathways of this biogas.

The multivariate techniques principal component analysis (PCA) and cluster analysis were applied to 

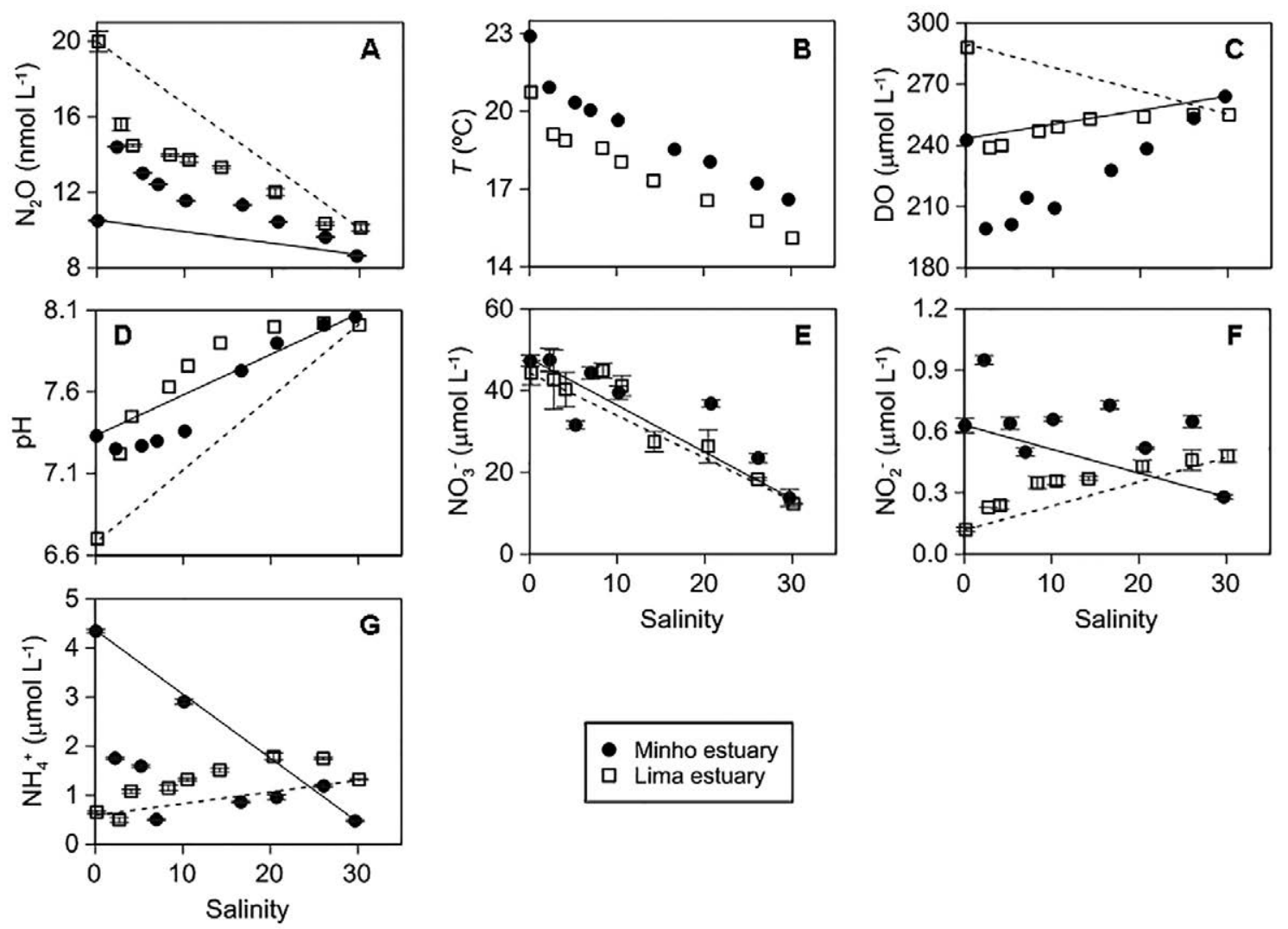

- Minho estuary

ㄴ Lima estuary

Fig. 2. $-\mathrm{N}_{2} \mathrm{O}$ and other environmental parameters against salinity in the Minho (black circles) and Lima (open squares) estuaries (error bars $= \pm 1$ standard deviation, sd). Conservative lines (solid line, Minho; dashed line, Lima) are shown when appropriate.

environmental data in order to identify and compare inter-relationships between these variables in both estuaries. Data were $\log (\mathrm{x}+1)$ transformed and handled using correlation-based PCA on the basis of standard Euclidean distance between samples to define their dissimilarity. PRIMER (version 6) was employed for the multivariate analysis.

Figures were created in Golden Software Grapher program (version 9.6.1001).

\section{RESULTS}

\section{$\mathrm{N}_{2} \mathrm{O}$ levels and fluxes}

Concentrations of $\mathrm{N}_{2} \mathrm{O}$ and the studied environmental parameters plotted against salinity along both Minho and Lima estuaries are shown in Figure 2.

Distribution of $\mathrm{N}_{2} \mathrm{O}$ exhibits a declining tendency towards the mouths of both estuaries. In general, concentrations were higher in Lima than in Minho (Fig. 2A). In Lima values ranged from 10.1 to $20.0 \mathrm{nmol}$ $\mathrm{L}^{-1}$ and were below the conservative mixing line. The maximum value was reached in the upper estuary, suggesting that the Lima River was the main source of $\mathrm{N}_{2} \mathrm{O}$ to the estuarine system. From salinity 0 to 4 a sharp decrease was observed, suggesting a greater $\mathrm{N}_{2} \mathrm{O}$ loss in the zone, presumably through water-air gas exchange. Downstream of salinity $4, \mathrm{~N}_{2} \mathrm{O}$ decreased more slightly and the mixing with the $\mathrm{N}_{2} \mathrm{O}$-poorer seawater is well perceptible. In the Minho estuary, concentrations var- ied from 8.6 to $14.4 \mathrm{nmol} \mathrm{L}^{-1}$ and by contrast with those observed in Lima were above the conservative mixing line, pointing to the existence of $\mathrm{N}_{2} \mathrm{O}$ sources within the estuary. A major concentration increase from 10.5 to $14.4 \mathrm{nmol} \mathrm{\textrm {L } ^ { - 1 }}$ was detected between 0 and 2.5 salinity, suggesting the existence of internal $\mathrm{N}_{2} \mathrm{O}$ sources in this zone of the estuary, presumably from manufacturing industries located nearby. $\mathrm{N}_{2} \mathrm{O}$ saturation values ranged from $101 \%$ to $166 \%$ along the Minho estuary and from $113 \%$ to $227 \%$ along the Lima estuary (see Table 4), indicating that both estuaries are potential $\mathrm{N}_{2} \mathrm{O}$ sources to the atmosphere.

Surface waters of both estuaries were well oxygenated during our study period. Concentrations of DO were higher than $280 \mu \mathrm{mol} \mathrm{L}{ }^{-1}$ in the upper Lima estuary at salinity 0.2 , decreasing to $240 \mu \mathrm{mol} \mathrm{L}-1$ at salinity 2.8 (Fig. 2C). Seawards of this salinity, an increasing tendency was observed and a concentration of $255 \mu \mathrm{mol} \mathrm{L}{ }^{-1}$ was also reached in the vicinity of the estuary mouth (salinity 30.2). In the Minho estuary, a decrease in DO was also detected in the upper estuary and the concentration dropped from $243 \mu \mathrm{mol} \mathrm{L}{ }^{-1}$ at 0.1 salinity to $199 \mu \mathrm{mol} \mathrm{L^{-1 }}$ at 2.3 salinity. Afterwards, a sharp increase in DO was measured along the estuary and a maximum value of $264 \mu \mathrm{mol} \mathrm{L}{ }^{-1}$ was reached at the estuary mouth (salinity 29.7). DO-enriched seawater probably accounted for the similar increasing trend seaward in both estuaries. Saturation values were higher than $70 \%$ in the Minho estuary and $90 \%$ in the Lima estuary. 

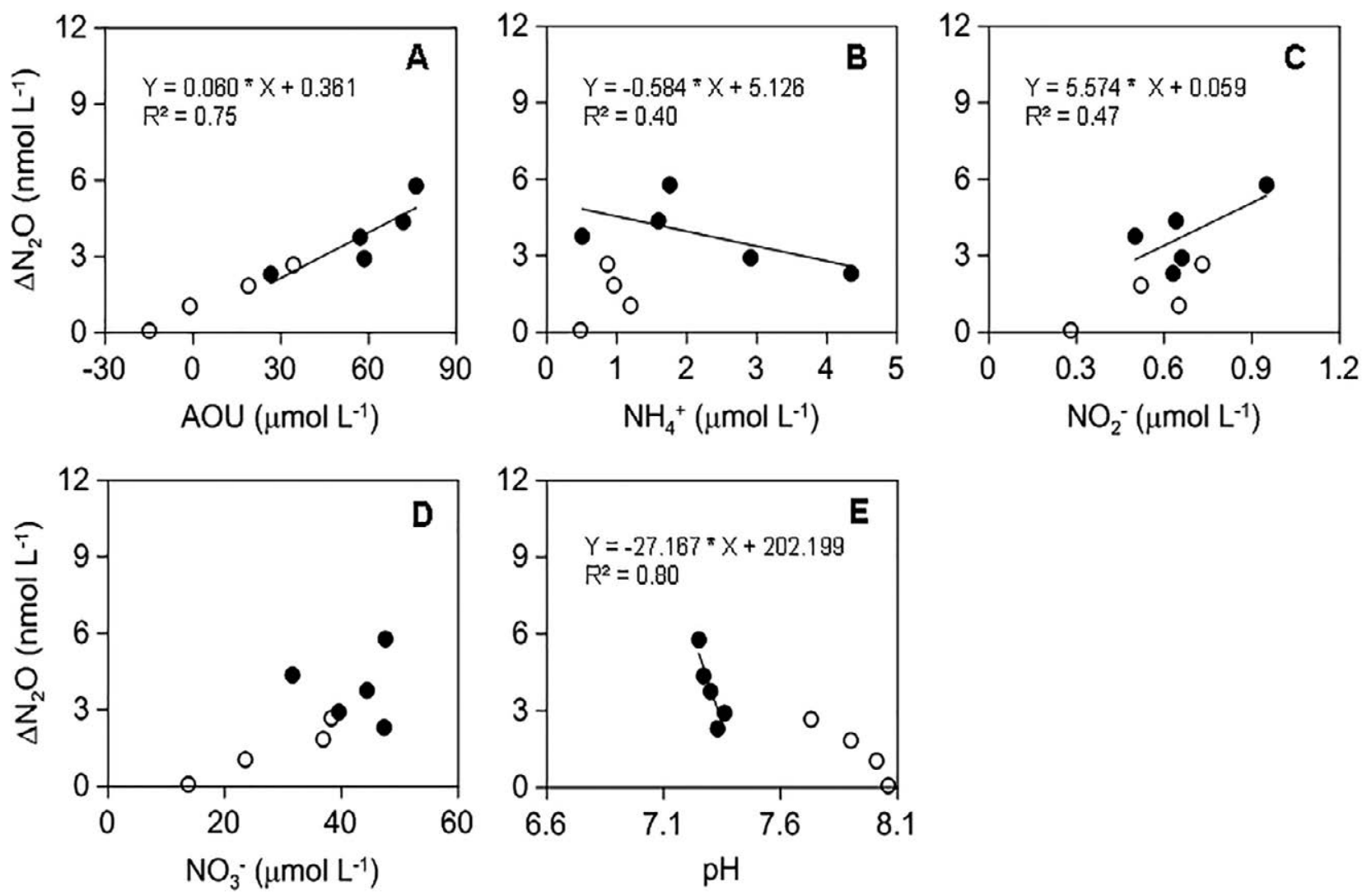

Fig. 3. - Relationships between $\Delta \mathrm{N}_{2} \mathrm{O}$ and environmental parameters in the Minho estuary. Lower salinity sites (0-10 salinity) are represented by black circles and higher salinity sites (15-30 salinity) by open circles. $\mathrm{R}^{2}$, correlation coefficient.
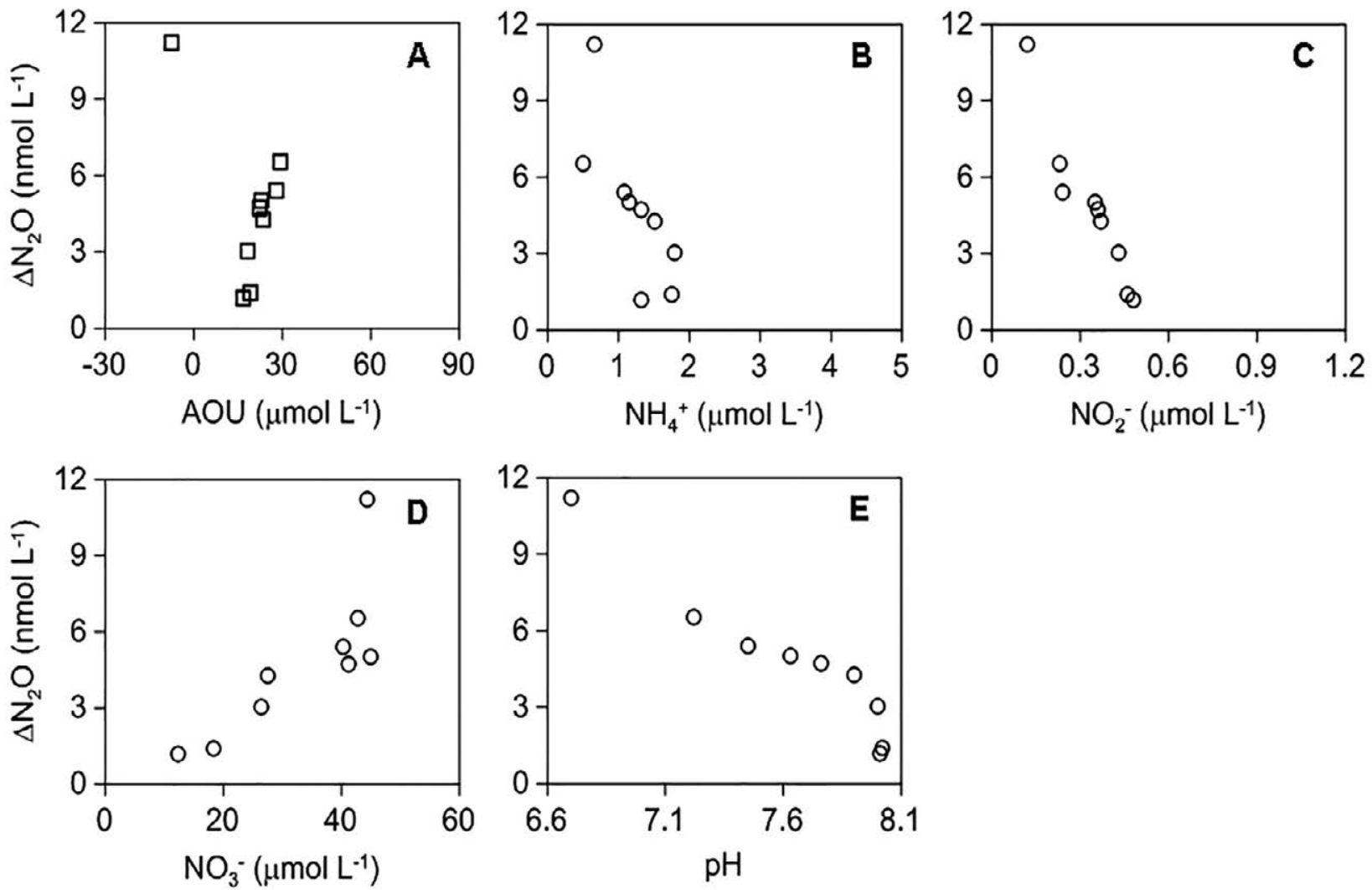

Fig. 4. - Relationships between $\Delta \mathrm{N}_{2} \mathrm{O}$ and environmental parameters in the Lima estuary. 
Table 3. - Results of principal component analysis showing loadings of variables for the first two principal components for the Minho and Lima estuaries.

\begin{tabular}{lllc}
\hline Environmental variable & PC1 & PC2 & PC3 \\
\hline Eigenvalues & 4.27 & 2.17 & 0.74 \\
\% Variation & 53.4 & 27.1 & 9.7 \\
Cum. \% Variation & 53.4 & 80.6 & 90.2 \\
\hline
\end{tabular}

In the Minho estuary $\mathrm{pH}$ increased from 7.3 in the more river-influenced zone to 8.1 at the estuary mouth (Fig. 2D). In the Lima estuary $\mathrm{pH}$ showed a larger range of values, increasing from 6.7 in the most riverinfluenced site to 8.0 at the estuary mouth.

$\mathrm{NO}_{3}{ }^{-}$was the dominant species of inorganic nitrogen in both estuaries, reaching a similar maximum concentration in the river input $\left(47.6 \mu \mathrm{mol} \mathrm{\textrm {L } ^ { - 1 }}\right.$ in Minho and $44.4 \mu \mathrm{mol} \mathrm{L}{ }^{-1}$ in Lima) (Fig. 2E). Values decreased seawards and in general followed the theoretical conservative mixing line. Along the Minho estuary both $\mathrm{NO}_{2}{ }^{-}$and $\mathrm{NH}_{4}{ }^{+}$exhibited an irregular behaviour, though the system seemed to function as an $\mathrm{NO}_{2}{ }^{-}$source and an $\mathrm{NH}_{4}{ }^{+}$sink (Fig. 2F, G). Between salinity 0 and $\sim 5-7$ the decline in $\mathrm{NH}_{4}{ }^{+}(\sim 4.0$ to $0.5 \mu \mathrm{M}$ $\left.\mathrm{L}^{-1}\right)$ was simultaneous with an increase in $\mathrm{NO}_{2}^{-}(\sim 0.6$ to $\left.1.0 \mu \mathrm{M} \mathrm{L}^{-1}\right)$ and $\mathrm{N}_{2} \mathrm{O}\left(\sim 10\right.$ to $\left.13-14 \mathrm{nmol} \mathrm{L}^{-1}\right)$, suggesting the occurrence of nitrification.

Figure 3 displays relationships between $\Delta \mathrm{N}_{2} \mathrm{O}$ and AOU, $\mathrm{NH}_{4}^{+}, \mathrm{NO}_{2}^{-}, \mathrm{NO}_{3}^{-}$and $\mathrm{pH}$ in the Minho estuary. In the mentioned salinity zone $(0$ and $\sim 5-7)$ a significant positive correlation was found between $\Delta \mathrm{N}_{2} \mathrm{O}$ and AOU $\left(\mathrm{R}^{2}=0.75\right)$. This indicates the occurrence of nitrification as a source of $\mathrm{N}_{2} \mathrm{O}$ and the respective slope provides an estimate of the biological $\mathrm{N}_{2} \mathrm{O}$ yield per mole $\mathrm{O}_{2}$ consumed (Yoshinari 1976). Further, the simultaneous (negative) correlations between $\Delta \mathrm{N}_{2} \mathrm{O}$ and the primary substrate for nitrification, $\mathrm{NH}_{4}^{+}$ $\left(\mathrm{R}^{2}=0.40\right)$, and $\mathrm{pH}\left(\mathrm{R}^{2}=0.80\right)$, and the positive correlation between $\Delta \mathrm{N}_{2} \mathrm{O}$ and the byproduct of nitrification, $\mathrm{NO}_{2}^{-}\left(\mathrm{R}^{2}=0.41\right)$, are consistent with the predominance

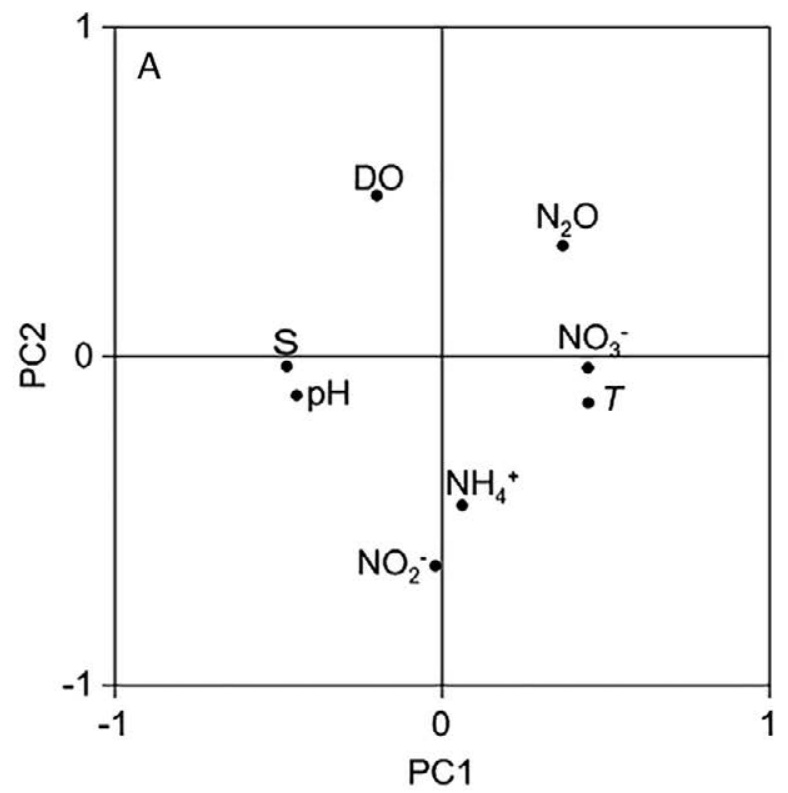

of nitrification as a mechanism of $\mathrm{N}_{2} \mathrm{O}$ production in the upper part of the Minho estuary. No correlation was found with $\mathrm{NO}_{3}{ }^{-}$, whose high concentrations were mostly riverine derived.

In the Lima estuary no relationships were found, suggesting the occurrence of nitrification (Fig. 4).

The application of PCA to the studied environmental variables in the Minho and Lima estuaries allowed us to identify two main composite variables, $\mathrm{PC} 1$ and PC2 (eigenvalues >1.0), which explain $82 \%$ of the variance (Table 3 ) and represent a good description of the environmental structure across the estuarine sampled sites.

PC1 explained $53 \%$ of variance and had the highest positive loading for $\mathrm{NO}_{3}{ }^{-}, \mathrm{T}$ and $\mathrm{N}_{2} \mathrm{O}$ and a negative loading for $\mathrm{S}$ and $\mathrm{pH}$ (Fig. 5). This component represents the separation of major river-influenced stations from major marine-influenced ones in both estuaries. PC2 explained $27 \%$ of the variance and correlated positively with $\mathrm{DO}$ and negatively with $\mathrm{NO}_{2}^{-}$and $\mathrm{NH}_{4}{ }^{+}$. This component appears to represent relevant parameters to $\mathrm{N}$ dynamics, particularly in Minho estuary. In fact, projection of stations along PC2 reveals a clear separation of sites from the upper Lima estuary (L1-L5) (Fig. 5), mostly associated with higher values of $\mathrm{N}_{2} \mathrm{O}$, and sites from the upper Minho (M1-M5) more associated with higher $\mathrm{NO}_{2}^{-}$and $\mathrm{NH}_{4}{ }^{+}$, apparently from river origin, as the $\mathrm{N}$ load from the Minho River is considerable at this point (Table 1). It was also observed that the stations from both middle/lower estuaries did not differ in terms of studied environmental variables.

$\mathrm{N}_{2} \mathrm{O}$ water-air fluxes are shown in Figure 6. Positive values prevailed at all stations but decreased, in general, between the upper and lower zone of the estuaries. This tendency was more pronounced in the Lima estuary, where higher $\mathrm{N}_{2} \mathrm{O}$ fluxes in the riverinfluenced area were about twice $\left(\sim 12.0 \mu \mathrm{mol} \mathrm{m} \mathrm{m}^{-2} \mathrm{~d}^{-1}\right.$; C96) (Fig. 6B) those observed in the upper part of the

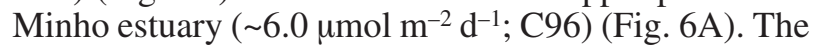

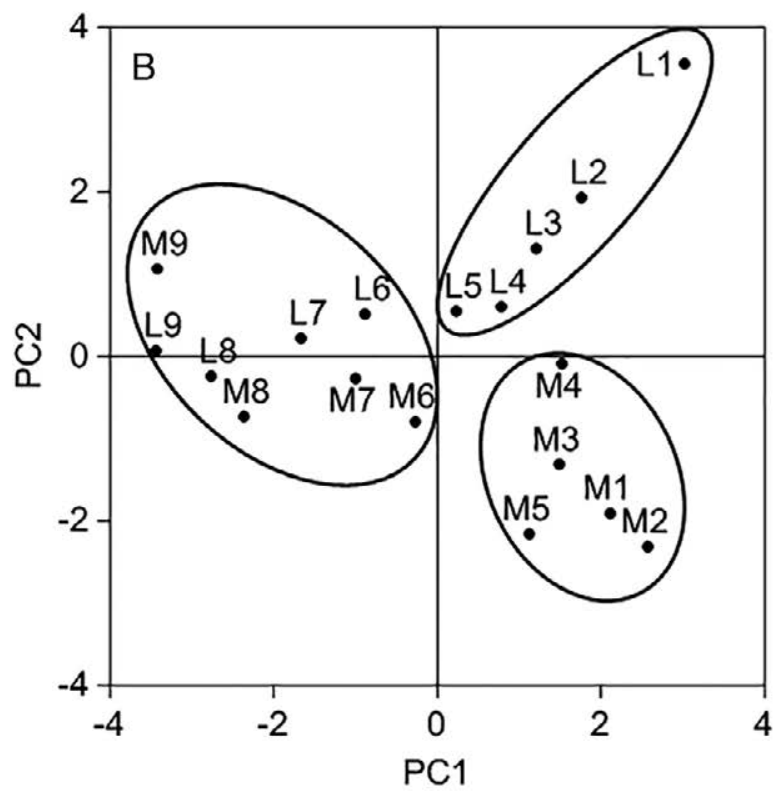

Fig. 5. - PCA ordination of variables loadings (A) and scores of sampling stations (B) in the Minho and Lima estuaries. 

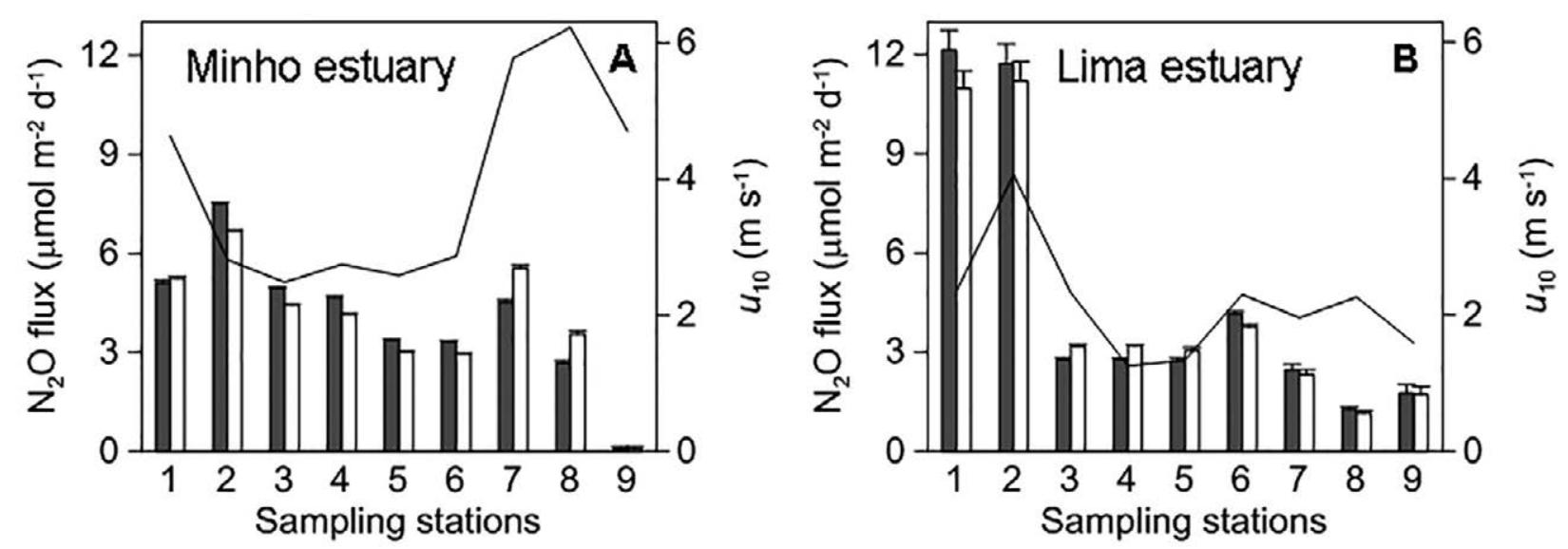

Fig. 6. - Water-air $\mathrm{N}_{2} \mathrm{O}$ fluxes (bar charts) along the Minho (A) and Lima (B) estuaries. Wind speed ( $\left.\mathrm{u}_{10}\right)$ is represented by solid line (Error bars $= \pm 1 \mathrm{sd}$ ).

higher fluxes in the Lima estuary were mainly associated with the higher levels of $\mathrm{N}_{2} \mathrm{O}$ observed in the upper estuary area (St.1 to St.3; Fig. 2), indicating that the low salinity zone (0-5) is an important source of $\mathrm{N}_{2} \mathrm{O}$ to the atmosphere.

Using the two different parameterizations (C96, RC01) to calculate the gas transfer coefficients, the averaged $\mathrm{N}_{2} \mathrm{O}$ water-air fluxes from Minho estuary to the atmosphere ranged between $4.0 \pm 3.3 \mu \mathrm{mol} \mathrm{m} \mathrm{m}^{-2} \mathrm{~d}^{-1}$ (RC01) and 4.1 $\pm 2.8 \mu \mathrm{mol} \mathrm{m} \mathrm{m}^{-2} \mathrm{~d}^{-1}$ (C96), corresponding to a mean $\mathrm{N}_{2} \mathrm{O}$ concentration of $11.3 \pm 1.3 \mathrm{nmol}$ $\mathrm{L}^{-1}(132 \pm 22 \%$ saturation) and a mean wind speed of $3.9 \pm 0.1 \mathrm{~m} \mathrm{~s}^{-1}$. Slightly higher $\mathrm{N}_{2} \mathrm{O}$ water-air fluxes were found in the Lima estuary, with averaged val-

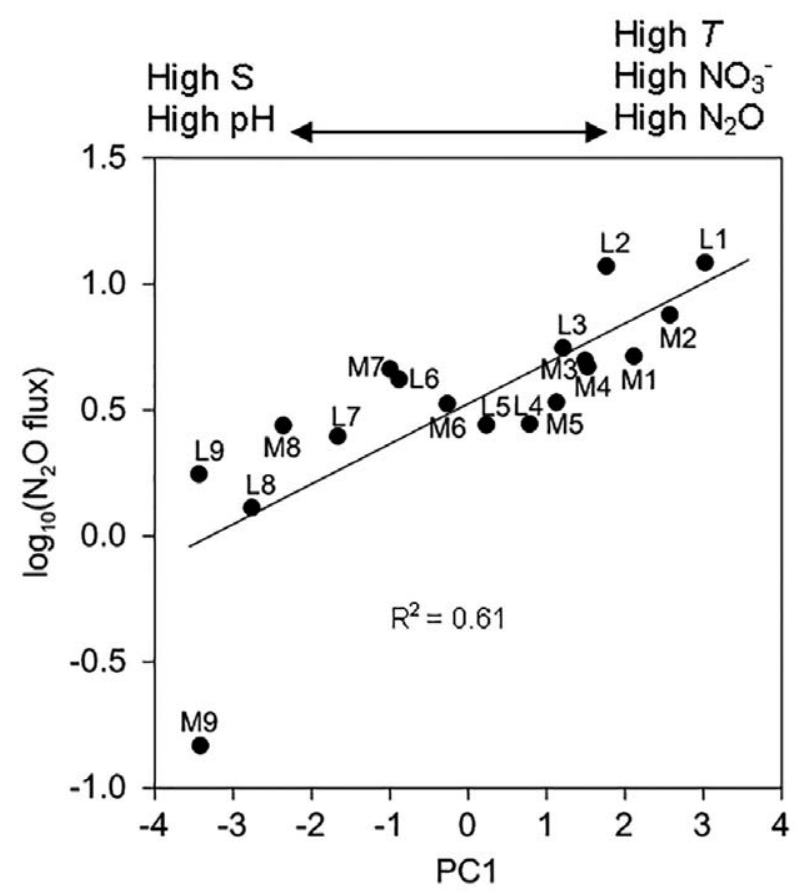

Fig. 7. - Relationship between log-transformed values of $\mathrm{N}_{2} \mathrm{O}$ fluxes and the first principal component in the Minho and Lima estuaries. $\mathrm{R}^{2}$, correlation coefficient. Variable trends are indicated along the top of the figure. ues ranging between $4.7 \pm 1.9 \mu \mathrm{mol} \mathrm{m} \mathrm{m}^{-2} \mathrm{~d}^{-1}(\mathrm{RC} 01)$ and 5.0 $\pm 2.0 \mu \mathrm{mol} \mathrm{m} \mathrm{m}^{-2} \mathrm{~d}^{-1}(\mathrm{C} 96)$, corresponding to a higher mean $\mathrm{N}_{2} \mathrm{O}$ concentration of $13.7 \pm 1.6 \mathrm{nmol} \mathrm{L}{ }^{-1}$ $(153 \pm 26 \%$ saturation) and a lower mean wind speed level $\left(2.4 \pm 0.1 \mathrm{~m} \mathrm{~s}^{-1}\right)$.

$\mathrm{N}_{2} \mathrm{O}$ fluxes from the Minho and Lima estuaries were regressed versus the first two PCs' ordination of station scores to test their ability to predict the fluxes. We found out that only $\mathrm{PC} 1$ showed to be correlated with $\mathrm{N}_{2} \mathrm{O}$ flux, with a strong positive correlation $\left(\mathrm{R}^{2}=0.61\right)$ (Fig. 7). $\mathrm{N}_{2} \mathrm{O}$ flux also increased along a gradient of increasing $\mathrm{NO}_{3}{ }^{-}$, T and $\mathrm{N}_{2} \mathrm{O}$. These results suggest that future global changes in these parameters will result in an increase of $\mathrm{N}_{2} \mathrm{O}$ flux in these estuarine systems.

\section{DISCUSSION}

The present study reveals that the Minho and Lima estuaries, particularly the upper reaches, behave differently regarding $\mathrm{N}_{2} \mathrm{O}$ levels, sources and fluxes. $\mathrm{N}_{2} \mathrm{O}$ distribution exhibits a pronounced spatial variability in both estuaries but in the Lima estuary concentrations are higher than in Minho. The Lima River was the main $\mathrm{N}_{2} \mathrm{O}$ contributor to the Lima estuary, whereas the occurrence of nitrification seems to represent an additional $\mathrm{N}_{2} \mathrm{O}$ source within the Minho estuary. As $\mathrm{NH}_{4}{ }^{+}$is a primary substrate for nitrification, low $\mathrm{NH}_{4}{ }^{+}$ concentration may limit nitrification. It has been suggested that the AOA and $\mathrm{AOB}$ niches are defined by ammonium concentrations (Martens-Habbena et al. 2009), with AOA dominating in ammonia-limited acid, whereas AOB have a tolerance of high ammonia concentrations.

Though no information on benthic AOA and AOB communities along the Minho and Lima estuaries is available, $\mathrm{NH}_{4}{ }^{+}$concentration in the upper Minho estuary (maximum $4.4 \mu \mathrm{mol} \mathrm{L}{ }^{-1}$ ) seems more suitable for the occurrence of nitrification than in the Lima estu-

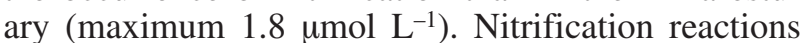
typically happen within a DO range of 15.6-78.0 $\mu \mathrm{mol}$ $\mathrm{L}^{-1}$, and the Minho and Lima surface waters were well 
Table 4. $-\mathrm{N}_{2} \mathrm{O}$ saturation, water-air fluxes and emissions for several world estuaries. Estimated using the relationships of ${ }^{\text {(a) }}$ Clark et al. (1995); (b) Carini et al. (1996); (c) Raymond and Cole (2001); (e) unpublished data.

\begin{tabular}{|c|c|c|c|c|c|c|}
\hline Estuaries & $\begin{array}{c}\text { Area } \\
\left(\mathrm{km}^{2}\right)\end{array}$ & $\begin{array}{l}\text { Saturation } \\
(\%)\end{array}$ & $\begin{array}{l}\text { Nitrous Oxide }(\mathrm{N} \\
\text { Water-air fluxes } \\
\left(\mu \mathrm{mol} \mathrm{m} \mathrm{m}^{-2} \mathrm{~d}^{-1}\right)\end{array}$ & $\begin{array}{l}\text { Emission } \\
\left(\mathrm{Mg} \mathrm{N}_{2} \mathrm{O}-\mathrm{N} \mathrm{yr}^{-1}\right)\end{array}$ & $\begin{array}{l}\text { Sampling } \\
\text { survey }\end{array}$ & Reference \\
\hline Loire, France & 41 & $84-271$ & $14.3^{\text {(a) }}$ & 6.1 & Single & de Wilde and de Bie (2000) \\
\hline Scheldt, Belgium & 269 & 710 & $66.6^{(a)}$ & $1.8 \times 10^{2}$ & Seasonal & de Wilde and de Bie (2000) \\
\hline Tagus, Portugal & 320 & $101-147$ & $-1.0-10.4$ (a) & $12.8-16.0^{(\mathrm{e})}$ & Seasonal & Gonçalves et al. (2010) \\
\hline Humber, UK & 303.6 & $100-4250$ & $76.6^{(a)}$ & $2.5 \times 10^{2}$ & Seasonal & Barnes and Upstill-Goddard (2011) \\
\hline Tay, UK & 121.3 & $100-118$ & $2.5^{\text {(a) }}$ & 2.5 & Single & Barnes and Upstill-Goddard (2011) \\
\hline Tyne, UK & 7.9 & $98-280$ & 7.5 & 0.37 & Seasonal & Barnes and Upstill-Goddard (2011) \\
\hline Ems, Germany & 162 & $181-1794$ & 76.7 (a) & $1.3 \times 10^{2}$ & Single & Barnes and Upstill-Goddard (2011) \\
\hline Gironde, France & 442 & $120-463$ & $25.5^{\text {(a) }}$ & $1.2 \times 10^{2}$ & Seasonal & Barnes and Upstill-Goddard (2011) \\
\hline Douro, Portugal & 2.4 & $280-650$ & $74.7^{\text {(a) }}$ & 1.9 & Single & Barnes and Upstill-Goddard (2011) \\
\hline Sado, Portugal & 180 & $91-162$ & $-2.2^{(\mathrm{b})}-3.8^{(\mathrm{c})}$ & $3.7-4.4$ & Single & Goncalves et al. (2015) \\
\hline Guadalete, Spain & $=$ & $96-2174$ & $-0.1-313.2$ & - & Seasonal & Burgos et al. (2015) \\
\hline Pearl River, China & 2789 & $101-3800$ & $0.1-733$ & $1.35 \times 10^{3}$ & Seasonal & Lin et al. (2016) \\
\hline Minho, Portugal & 23 & $101-166$ & $4.0^{(\mathrm{c})}-4.1^{(\mathrm{b})}$ & $0.94-0.96$ & Single & This study \\
\hline Lima, Portugal & 5.4 & $113-227$ & $4.7^{(\mathrm{c})}-5.0^{(\mathrm{b})}$ & $0.26-0.28$ & Single & This study \\
\hline
\end{tabular}

above these concentrations, leading to nitrification conditions. However, only in the upper Minho do correlations found between $\Delta \mathrm{N}_{2} \mathrm{O}$ and $\mathrm{AOU}, \mathrm{NH}_{4}^{+}$and $\mathrm{NO}_{2}^{-}$suggest that nitrification may have been acting as an $\mathrm{NH}_{4}{ }^{+}$sink and a source of $\mathrm{N}_{2} \mathrm{O}$. The calculated biological $\mathrm{N}_{2} \mathrm{O}$ yield $\left(0.060 \mathrm{nmol}\right.$ per $\mu \mathrm{mol} \mathrm{O} \mathrm{O}_{2}$ consumed $)$ falls within the range observed in marine systems and in particular in the Atlantic off the Iberian coast (Nevison et al. 2003). The effect of salinity on nitrification is well documented and in many estuarine systems nitrification rates are highest at lower and intermediate salinities (Bianchi et al. 1999, Teixeira et al. 2013). Our results from the upper Minho are in accordance with these findings, as the potential nitrification occurred at low salinity (between $\sim 2$ and $\sim 10$ ). The community composition of nitrifying microbes is very dependent on salinity, but a combination of other environmental factors may shape AOB diversity along an estuary (Mosier et al. 2008).

$\mathrm{pH}$ may regulate nitrification, and Wild et al. (1971) found an ideal $\mathrm{pH}$ range for nitrification between 7.5 and 8.5. As nitrifiers are known to decrease $\mathrm{pH}$, the sharp negative correlation found between $\mathrm{pH}$ and $\Delta \mathrm{N}_{2} \mathrm{O}$ in the $\mathrm{pH}$ range 7.2-7.4 in the upper Minho estuary (Fig. 3E) may be a direct result of nitrification. $\mathrm{N}_{2} \mathrm{O}$ saturation values ranging from $101 \%$ to $166 \%$ in the Minho estuary and $113 \%$ to $227 \%$ in the Lima estuary indicate that both estuaries behave as a potential $\mathrm{N}_{2} \mathrm{O}$ source to the atmosphere. Positive $\mathrm{N}_{2} \mathrm{O}$ water-air fluxes prevailed in all sampling stations, decreasing in general from upper to lower estuaries. However, this tendency was more pronounced in the Lima estuary, where higher $\mathrm{N}_{2} \mathrm{O}$ fluxes in the river-influenced area were about twice $\left(\sim 12.0 \mu \mathrm{mol} \mathrm{m} \mathrm{m}^{-2} \mathrm{~d}^{-1}\right.$; C96) those observed in the upper part of the Minho estuary $(\sim 6.0$ $\mu \mathrm{mol} \mathrm{m} \mathrm{m}^{-2} \mathrm{~d}^{-1}$; C96). It is likely that a greater turbulence of Minho upper estuary waters leads to a more rapid degassing of $\mathrm{N}_{2} \mathrm{O}$ to the atmosphere in this part of the system.

Estimated $\mathrm{N}_{2} \mathrm{O}$ fluxes were similar to those reported from the Portuguese Tagus and Sado estuaries (Gonçalves et al. 2010, 2015) (Table 4) but much lower than that of the Douro estuary (Barnes and Upstill-Goddard 2011). These fluxes were also much lower than those reported from the Scheldt estuary in Belgium, the Ems estuary in Germany, the Humber estuary in the UK, the Guadalete estuary in Spain and the Pearl River estuary in China (Table 4).

Though $\mathrm{N}_{2} \mathrm{O}$ water-air fluxes were obtained during a single sampling, aware of the seasonal variability that characterizes these estuarine systems, we estimated the annual contribution of Minho and Lima estuaries to the global $\mathrm{N}_{2} \mathrm{O}$ emissions. Taking into account estuarine areas $\left(23 \mathrm{~km}^{2}\right.$ for Minho and $5.4 \mathrm{~km}^{2}$ for Lima) and the estimated mean $\mathrm{N}_{2} \mathrm{O}$ fluxes, we extrapolated an emission of $0.94-0.96 \mathrm{Mg} \mathrm{N}_{2} \mathrm{O}-\mathrm{N} \mathrm{yr}^{-1}$ (estimated using RC01 and C96, respectively) for the Minho estuary and 0.26-0.28 $\mathrm{Mg} \mathrm{N}_{2} \mathrm{O}-\mathrm{N} \mathrm{yr}^{-1}$ (RC01 and C96, respectively) for the Lima estuary.

On a global perspective, estimated $\mathrm{N}_{2} \mathrm{O}$ emissions from the Minho and Lima estuaries $\left(<1.0 \mathrm{Mg} \mathrm{N} \mathrm{N}_{2} \mathrm{O}-\mathrm{N}\right.$ $\left.\mathrm{yr}^{-1}\right)$ represent a reduced fraction $(<0.02 \%)$ of emissions from European estuaries $\left(6.8 \mathrm{Gg} \mathrm{N}_{2} \mathrm{O} \mathrm{yr}{ }^{-1}\right.$, Barnes and Upstill-Goddard 2011). Nevertheless, being aware of our unique seasonal sampling, and particularly the higher values of $\mathrm{N}_{2} \mathrm{O}$ emissions measured in winter spring and in other Portuguese estuaries (Gonçalves et al. 2010), more studies assessing the seasonal variability of $\mathrm{N}_{2} \mathrm{O}$ emissions in our systems are needed.

\section{ACKNOWLEDGEMENTS}

Acknowledgements are due to colleagues from the IPMA Oceanography Laboratory for their assistance in sampling, technical and analytical procedures. The authors also want to thank the Instituto Hidrográfico for their assistance during sampling. The research was supported by the PoPesca MARE project (22-05-01FDR-001) and by the FCT-Portuguese Foundation of Science and Technology (POCI 2010 and FSE) through grant SFRH/BD/28569/2006.

\section{REFERENCES}

Aminot A., Chaussepied M. 1983. Manuel des analyses chimiques en milieu marin. Centre National pour l'Exploitation des Océans. CNEXO, Brest, France, 395 pp.

Bange H.W., Freing A., Kock A., et al. 2010. Marine pathways to nitrous oxide. In: Smith K.A. (ed.), Nitrous oxide and climate change. Earthscan, London. U.K. pp. 36-62.

Barnes J., Upstill-Goddard R.C. 2011. $\mathrm{N}_{2} \mathrm{O}$ seasonal distributions and air-sea exchange in UK estuaries: Implications for the trop- 
ospheric $\mathrm{N}_{2} \mathrm{O}$ source from European coastal waters. J. Geophys. Res. B. 116: G01006.

https://doi.org/10.1029/2009JG001156

Bettencourt A., Ramos L., Gomes V., et al. 2003. Estuários Portugueses. Editions INAG - Ministério das Cidades, Ordenamento do Território e Ambiente, Lisboa, 311 pp.

Bianchi M., Feliatra F., Lefevre D. 1999. Regulation of nitrification in the land-ocean contact area of the Rhône River plume (NW Mediterranean). Aquat. Microb. Ecol. 18: 301-312. https://doi.org/10.3354/ame018301

Bollmann A., Laanbroek H.J. 2002. Influence of oxygen partial pressure and salinity on the community composition of ammonia-oxidizing bacteria in the Schelde estuary. Aquat. Microb. Ecol. 28: 239-247. https://doi.org/10.3354/ame028239

Burgos M., Sierra A., Ortega T., et al. 2015. Anthropogenic effects on greenhouse gas $\left(\mathrm{CH}_{4}\right.$ and $\left.\mathrm{N}_{2} \mathrm{O}\right)$ emissions in the Guadalete River Estuary (SW Spain). Sci. Total Environ. 503-504: 179-189. https://doi.org/10.1016/j.scitotenv.2014.06.038

Carini S., Weston N., Hopkinson C., et al. 1996. Gas exchange rates in the Parker River estuary, Massachusetts. Biol. Bull. 191: 333-334. https://doi.org/10.1086/BBLv191n2p333

Clark J.F., Schlosser P., Simpson K.J, et al. 1995. Relationship between gas transfer velocities and wind speeds in the tidal Hudson River determined by the dual tracer technique. In: Jhane B. Monahan E. (eds), Air-Water Gas Transfer. AEON Verlag and Studio, Germany, pp. 785-800.

Dai M., Wang L., Guo X., et al. 2008. Nitrification and inorganic nitrogen distribution in a large perturbed river/estuarine system: the Pearl River Estuary, China. Biogeosci. 5: 1227-1244. https://doi.org/10.5194/bg-5-1227-2008

de Bie M.J.M., Middelburg J.J. Starink M., et al. 2002. Factors controlling nitrous oxide at the microbial community and estuarine scale. Mar. Ecol. Prog. Ser. 240: 1-9. https://doi.org/10.3354/meps240001

de Wilde H.P.J., de Bie M.J.M. 2000. Nitrous oxide in the Schelde estuary: Production by nitrification and emission to the atmosphere. Mar. Chem. 69: 203-216. https://doi.org/10.1016/S0304-4203(99)00106-1

Dong L.F., Nedwell D.B. 2006. Sources of nitrogen used for denitrification and nitrous oxide formation in sediments of the hypernutrified Colne, the nutrified Humber and oligotrophic Conwy Estuaries, United Kingdom. Limnol. Oceanogr. 51(1, part 2): 545-557. https://doi.org/10.4319/1o.2006.51.1 part 2.0545

Ferreira J.G., Nobre A.M., Simas T.C., et al. 2005. Monitoring plan for water quality and ecology for Portuguese traditional and coastal waters: Development of guidelines for the application of the European Union Water Framework Directive. Editions INAG-Instituto da Água IMAR-Institute of Marine Research. Lisbon, Portugal, 142 pp.

Gonçalves C., Brogueira M.J., Camões M.F. 2010. Seasonal and tidal influence on the variability of nitrous oxide in the Tagus estuary, Portugal. Sci. Mar. 74S1: 57-66 https://doi.org/10.3989/scimar.2010.74s1057

Gonçalves C., Brogueira M.J, Nogueira M. 2015. Tidal and spatial variability of nitrous oxide $\left(\mathrm{N}_{2} \mathrm{O}\right)$ in Sado estuary (Portugal). Est. Coast. Shelf Sci. 167: 466-474. https://doi.org/10.1016/j.ecss.2015.10.028

Hartman B., Hammond D. 1985. Gas exchange in San Francisco Bay. Hydrobiology 129: 59-68. https://doi.org/10.1007/BF00048687

Lin H., Dai M., Kao S.J. et al. 2016. Spatio temporal variability of nitrous oxide in a large eutrophic estuarine system: The Pearl River Estuary, China. Mar. Chem. 182: 14-24. https://doi.org/10.1016/j.marchem.2016.03.005

Martens-Habbena W., Berube P.M., Urakawa H., et al. 2009. Am- monia oxidation kinetics determine niche separation of nitrifying Archaea and Bacteria. Nature 461: 976-981.

https://doi.org/10.1038/nature08465

Mosier A.C., Francis C.A. 2008. Relative abundance and diversity of ammonia-oxidizing archaea and bacteria in the San Francisco Bay estuary. Environ. Microbiol. 10: 3002-3016. https://doi.org/10.1111/j.1462-2920.2008.01764.x

Murray R.H., Erler D.V., Eyre B.D. 2015. Nitrous oxide fluxes in estuarine environments: response to global change. Global Change Biol. 21: 3219-3245. https://doi.org/10.1111/gcb.12923

Myhre G., Shindell D., Bréon F.M., et al. 2013. Anthropogenic and Natural Radiative Forcing. In: Stocker T.F., Qin D., Plattner G.K., et al. (eds), Climate Change 2013: The Physical Science Basis. Contribution of Working Group I to the Fifth Assessment Report of the Intergovernmental Panel on Climate Change. Cambridge University Press, pp. 659-740. https://doi.org/10.1017/CBO9781107415324.018

Nevison C.D., Butler J.H., Elkins J.W. 2003. Global distribution of $\mathrm{N}_{2} \mathrm{O}$ and the $\Delta \mathrm{N}_{2} \mathrm{O}$-AOU yield in the subsurface ocean. Global Biogeochem Cycles 17: 1119. https://doi.org/10.1029/2003GB002068

Prather M.J., Holmes C.D., Hsu J. 2012. Reactive greenhouse gas scenarios: Systematic exploration of uncertainties and the role of atmospheric chemistry. Geophys. Res. Lett. 39: L09803. https://doi.org/10.1029/2012GL051440

Ramos S., Cowen R.K., Ré P., et al. 2006. Temporal and spatial distributions of larval fish assemblages in the Lima estuary (Portugal). Est. Coast. Shelf Sci. 66: 303-314. https://doi.org/10.1016/j.ecss.2005.09.012

Raymond P.A., Cole J.J. 2001. Gas exchange in rivers and estuaries: choosing a gas transfer velocity. Estuaries 24: 312-317. https://doi.org/10.2307/1352954

SNIRH (Sistema Nacional de Informação de Recursos Hídricos). 2013. Instituto da Água IP. http://snirh.pt

Sousa C., Vaz M.N., Alvarez I., et al. 2013. Effect of Minho estuarine plume on Rias Baixas: numerical modeling approach. J. Coast. Res. Spec. 65: 2059-2065. https://doi.org/10.2112/SI65-348.1

Strauss E.A., Mitchell N.L., Lamberti G.A. 2002. Factors regulating nitrification in aquatic sediments: effects of organic carbon, nitrogen availability, and $\mathrm{pH}$. Can. J. Fish. Aquat. Sci. 59: 554-563. https://doi.org/10.1139/f02-032

Teixeira C., Magalhães C., Joye S.B., et al. 2013. The role of salinity in shaping dissolved inorganic nitrogen and $\mathrm{N}_{2} \mathrm{O}$ dynamics in estuarine sediment-water interface. Mar. Pollut. Bull. 66: 225-229. https://doi.org/10.1016/j.marpolbul.2012.11.004

Wanninkhof R. 1992. Relationship between wind speed and gas exchange over the ocean. J. Geophys. Res. C 97(C5): 7373-7382. https://doi.org/10.1029/92JC00188

Weiss R.F. 1970. The solubility of nitrogen, oxygen, and argon in water and seawater. Deep-Sea Res. Oceanogr. Abstr. 17: 721-735. https://doi.org/10.1016/0011-7471(70)90037-9

Weiss R.F., Price B.A. 1980. Nitrous oxide in water and seawater. Mar. Chem. 8: 347-359. https://doi.org/10.1016/0304-4203(80)90024-9

Wild H.E., Sawyer C.N., McMahon T.C. 1971. Factors affecting nitrification kinetics. J. Water Pollut. Control Fed. 43: 1845-1854.

WMO (World Meteorological Organization). 2006. World Meteorological Organization greenhouse gas bulletin: The State of Greenhouse Gases in the Atmosphere Using Global Observations through 2006. Bulletin No. 3. Global Atmosphere Watch, Geneva, Switzerland, 4 pp.

Yoshinari T. 1976. Nitrous oxide in the sea. Mar. Chem. 2: 189-202. 